\title{
Business Model and Performance of Firms
}

\author{
Jean Michel Sahut ${ }^{1,2}$, Lubica Hikkerova ${ }^{3} \&$ Moez Khalfallah ${ }^{3}$ \\ ${ }^{1}$ Geneva School of Business Administration, University of Applied Sciences Western Switzerland, Switzerland \\ ${ }^{2}$ CEREGE EA 1722, University of Poitiers, France \\ ${ }^{3}$ IPAG Business School, Paris, France \\ Correspondence: Jean Michel Sahut, Geneva School of Business Administration, Switzerland. E-mail: \\ jmsahut@gmail.com
}

Received: May 25, 2012

Accepted: June 7, $2012 \quad$ Online Published: December 31, 2012

doi:10.5539/ibr.v6n2p64

URL: http://dx.doi.org/10.5539/ibr.v6n2p64

\begin{abstract}
This paper proposes to clarify the concept of business model, its usage and how it can contribute to the firm's value creation. The literature review shows a board diversity of definitions and application complexity in the firm. The paper identifies the emergence of the business model and how it evolves to the "e-Business model" with commercial development of Internet. Then, it exposes the general typology, roles and the evolution of business model in recent years, whether in quantity or quality studies. Finally, the connection between the business model concept and the company's performance is explained by the analysis of some recent studies. We also illustrated this relationship through comparing the business model of internet banks and the business model of the traditional banks.
\end{abstract}

Keywords: business model, new economy, performance, ICT, internet bank

\section{Introduction}

The term "Business Model" is widespread and it is becoming commonly used. Thus, using the Google search engine to explain the exact phrase "business model", Chesbrough and Rosenbloom have identified 107.000 occurrences in May 2000, while Warnier et al. (2004) have found out 1.26 million hits in January 2004 and we recorded 2.16 million hits in September 2004 and 30.2 million hints in March 2007. Actually, the number of web pages has increased dramatically over this period. This quick investigation shows that the concept is highly mobilized and that its use is growing, despite the bursting of the dotcom bubble, an online world to which it is often closely associated.

The birth of the concept of "business model" (BM) goes back to the 1960s but it has actually emerged since the mid-1990s with the development of Internet services, information and communication technology and more generally of the "new economy". The mutations that were responsible for its development are not only technological, but there are also economic factors such as searching for shareholder value creation and also regulatory factors, especially the deregulation of the telecom sector, which had a significant influence and led to the emergence of new businesses, creating revenue models, and complexity of inter-firm relations (Redis, 2007).

Therefore, these changes have required new analytical frameworks and concepts including the Business model so as to better understand them and integrate them into the strategy of firms.

The outstanding success of the high-tech industries and information and communication industries opens up new perspectives on how revenues can be generated. The business model has proven to be a vital tool to understand the mechanisms through which a company captures value (Osterwalder \& Pigneur, 2003).

The concept of business model was then constructed through successive additions and sedimentation of numerous articles, reports and books that came to clarify its meaning over time. While some works are interested in formalizing and defining the business model and its application fields, the business model transcends a purely descriptive or ontological dimension (Lecocq et al., 2010). Indeed, its emergence is linked to the need of explaining how firms are able to create and capture value in an integrative approach.

Furthermore the business model joins the Resource-Based View, which assumes that the firm's ability to hold recoverable, rare, improperly imitable and sustainable resources is the source of sustainable performance (Barney, 1991). However, the business model takes into account the complementary dimensions to explain 
differences in how to exploit resources. In this respect, the business model explains firms' performance as resulting from their heterogeneity, which broadly paves the way for its implementation as an explanatory framework for this performance. This notion of the business model seems increasingly interesting researchers. The latter intend to explain how they allow the firm to create and capture value (Amit \& Zott, 2001; Chesbrough \& Rosenbloom, 2002; Osterwalder \& Pigneur, 2003; Malone et al., 2006).

This paper, therefore, aims to explain the emergence of the concept of Business model, its structure and its development as a research topic, and its explanatory power on firm performance.

The remainder of this paper is organized as follows; Section II describes the conceptualization of the notions of Business model (BM) and e-Business model (e-BM). Section II reviews the evolution of academic work and the emergence of the BM. Section IV illustrates the relationship between business models and firms performance. Section $\mathrm{V}$ is a conclusion.

\section{The Concepts}

\subsection{The Emergence of Business Model Concept and EBM}

This section aims at showing the foundations of the concept of "Business model" (BM), which brought about many definitions in the scientific literature, given its dynamic dimensions such as value creation, competitiveness, and shift.

The oldest and most conclusive essay on the definition of the BM concept is that of Viscio and Pasternack (1996). They provide a very theoretical vision of BM which is assimilated to a business model. According to Viscio and Pasternack's definition, a BM is made up of five elements that form a value system whose total value exceeds that of the whole parts: the core unit, the business units, distribution service, governance and links. This notion describes internal and external businesses of a firm and their own objective too.

This vision has been already completed by Timmers' approach (1998). He defines a BM as follows:

- A structure for the flow of products, services and information including a description of the different actors in the model and their roles,

- A description of the benefits of each actor in the model,

- A description of revenue sources.

Other authors have then extended this vision. Linder and Cantrell (2000) asserted: "It's a rich, tacit understanding about how all pieces work together to make money". These authors support this view of the BM since $62 \%$ of interviewed managers had difficulty describing their BM beyond its success (Note 1). Whereas Loilier and Tellier (2001) maintain that a BM can be likened to the way in which the company creates value.

In fact, defining what a BM is a difficult tasking because it is associated with dynamic dimensions such as value creation, competitiveness and change.

Porter (2001), in particular, has described this concept as "fuzzy", "superficial", and theoretically difficult to understand. Moreover, Magretta (2002) points to the current error vis-à-vis the BM is to consider them as a strategy: "Business modeling is the managerial equivalent of the scientific method - you start with a hypothesis, which you can test in practice and revise when necessary".

Whatever the obtained definition, it is important to differentiate between the BM concept and its strategy and to consider it as a dynamic concept that is constantly challenged by market conditions, the state of the industry, the firm's performance, its networks, etc.

\subsection{From Business Model to E-BM}

Commercial development of Internet has accelerated the creation of new BM and redefined existing ones (Applegate, 2001).

Actually, Internet is not merely a new distribution channel, but it affects all types of activities of the value chain and it has created "new ways of doing business" called "e-Business".

For instance, Internet reinforces Research \& Development (support activity following Porter's concept of value chain) assisting in the group design of products between the sites and participants in the value system, and by listing the concepts accessible to all branches of the company giving the real-time access to all databases of sales and services. Internet also helps reduce orders transmission time by automating both the relationship with customers and suppliers and set up an integrated real management. The impact of such practices over the efficiency of work is to create added value for the company (Porter, 2001). 
Similarly, the term "Electronic Business Model" (e-BM) has emerged in the literature to describe the BM of e-business. Being a concept derived from that of BM, it is equally difficult to define it and to approach it differently. Therefore, many authors have tried to define a heuristic approach that is to say from their own observations of the market. In practice, both terms are used interchangeably, mainly in the ICT sector.

This produced a variety of studies both in the number of identified e-BMs and their characteristics: Timmers (1998) has eleven different types, Rappa (2002) has nine, and five for Loilier and Tellier (2001).

Each author, when dealing with the characteristics chosen to establish his typology, refers to various theoretical and practical dimensions (Table 1).

Table 1. Examples of e-BM classification dimensions

\begin{tabular}{ll}
\hline Author & Dimension \\
\hline Timmers (1998) & - Level of functional integration (a single function to multiple functions); \\
& - Degree of innovation (low or high); \\
& - Impact on value chain. \\
& - Market structure; \\
Mahadevan (2000) & - Target market (B-to-B ou B-to-C). \\
& - The sources of differentiation (clean inventory, online sales, online sales, online fixed \\
Applegate (2001) & price, products, level of customization, etc.); \\
& - Sources of income; \\
& - The incurred costs. \\
& - Revenue models; \\
Novak and Hoffman (2001) & - The customers value models. \\
\hline
\end{tabular}

Although there are many similarities, comparisons are often approximate regarding the divergence of the chosen dimensions. Indeed, Timmers (1998) has a much centered vision on the internal dynamics of e-BM and their interactions with the environment. As to Mahadevan (2000), he favors a "macro" vision in which the e-BM depends on the types of the relationships between actors in a given market. Neither author considers the generated income or incurred costs but they slightly tackle value creation. Similarly, studies that have investigated these aspects turned to be approached either separately or partially.

Applegate (2001) provided a partial solution suggesting a classification of sources of income into four main categories: business, content, community, and infrastructure revenue.

Applegate classification of e-BM is very specific about the creation of value for the e-BM (sources of differentiation of revenue and incurred costs) but the customers' created value customers is not essential. The only thought that reconciles these different dimensions is that of Hoffman and Novak (2001). They define an e-BM as a combination of a revenues model and a model of customer value (Figure 1).

\section{Revenue Model (R)}

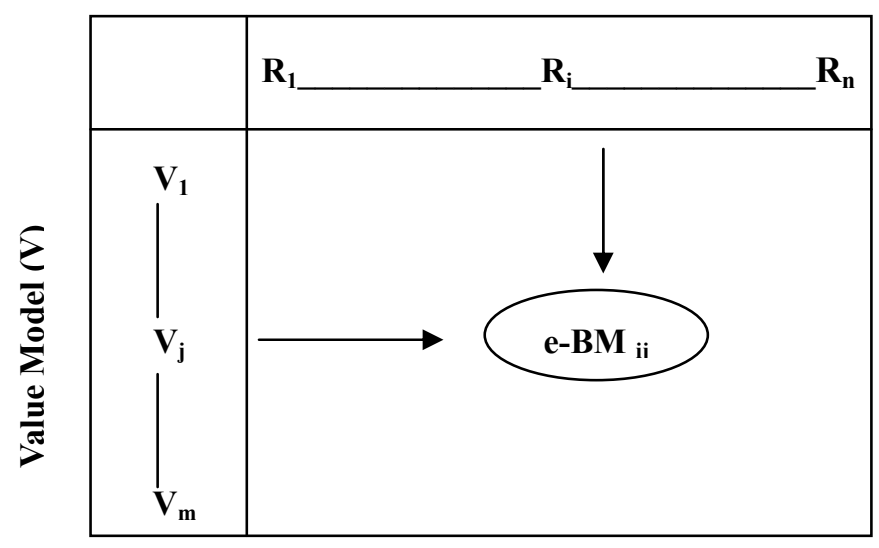

Figure 1. Values, revenues and "Customer Model Integration"

Source: Adapted from Novak et Hoffman (2001). 
In Fact, Novak and Hoffman have presented a "Customer Model Integration" in which the definition of an e-BM is related to both "the value patterns for customers" (value model) and "revenue models" (revenue model). It is then possible to identify twelve model values (Table 2).

Table 2. Value models for customers

\begin{tabular}{|c|c|c|}
\hline Value models & Value created for customers & Example of firms \\
\hline Brokerage & Facilitate the contact between salespersons and buyers (B2B, B2C or C2C markets). & $\begin{array}{l}\text { eBay } \\
\text { Priceline.com }\end{array}$ \\
\hline Content & Satisfy all information needs & About.com \\
\hline Search & Target the needed information. & Google.com \\
\hline Incentive & $\begin{array}{l}\text { It has to do with offering points to customers, who at a certain threshold-value, may benefit from } \\
\text { some products and services. }\end{array}$ & $\begin{array}{l}\text { Mypoints.com } \\
\text { Webmiles.com }\end{array}$ \\
\hline Freeware & Customers have access to free and useful software. & Gratuiciel.com \\
\hline Communication & A free e-mail and that service or online telephony. & Skype.com \\
\hline Control & $\begin{array}{l}\text { The pressure brought by groups of customers at the protection of privacy, property rights of the } \\
\text { content and boycot unethical content is a contribution in value. }\end{array}$ & Anonymizer.com \\
\hline Outsourcing & $\begin{array}{l}\text { The client is directly connected to the Internet-ERP producer for greater control of their } \\
\text { applications. }\end{array}$ & iprint.com \\
\hline Entertainment & $\begin{array}{l}\text { The concept is based on providing specific information to a particular area of interest, or an } \\
\text { entertainment program. }\end{array}$ & M6.fr \\
\hline Transaction & $\begin{array}{l}\text { The customer has access to stores normally not accessible geographically, and this is } \\
\text { through a theme collection. }\end{array}$ & Retromodern.com \\
\hline Affiliate & $\begin{array}{l}\text { This model is oriented towards SMEs which want to make themselves known on the web. The } \\
\text { payment of advertising costs is limited to the number of clicks on the banner only. }\end{array}$ & $\begin{array}{l}\text { Amazon.com } \\
\text { Art.com }\end{array}$ \\
\hline Community & $\begin{array}{l}\text { Customers can identify users with whom they want to establish various types of relations based on } \\
\text { affinity research tools. }\end{array}$ & Epinions.com \\
\hline
\end{tabular}

But these revenue models and clients' created value are not exhaustive for two main reasons:

- Given the difficulty of defining a single typology of e-BM, you can submit as many models as there are combinations of income sources, the emergence of a new e-BM means that there is a new original combination of revenue sources, or even creating a new revenue-generating element;

- In addition to Applegate's, other sources of revenue may exist. Novak and Hoffman (2001) identify the sale of customer data (emails, addresses, buying behaviours, etc...), in-store purchase after checking the products on the Internet or efficiency proofs, as the real sources of revenue for e-BM.

In the literature, these articles were followed by another stage of describing the elements of the BM rather than listing its components or identifying the different types of value. Afuah and Tucci (2003) particularly consider the BM as a basket of activities that allow a firm to earn money in a sustainable way. Their approach focuses on value creation among several actors. Therefore, A BM must provide answers to the following questions: What type of value proposal is made to customers? Which categories of customers are targeted by the value proposal? How is it possible to assess the value proposal and evaluate its price? Who is going to pay? What is the underlying strategy for value proposal? How can a value proposal be construed? How can we preserve the benefit gained from this value proposal?

To sum up (Figure 2), we can define a business model as a combination of three elements: a value proposal to the customer, making this value proposal and a revenue model (how the proposal of value is paid?).

Thus, the concept of BM rests on another concept "value proposal" which was actually coined by management gurus to characterize innovation "product". This notion further clarifies the value or benefits perceived by customers, in addition to the company's products or services.

Furthermore, the type of activity strongly influences the structure of a given industry (Porter, 2001). As a result, the e-BMs are much different from one sector to another. For this reason, the definition of the types of inter-industry BM is very difficult. 


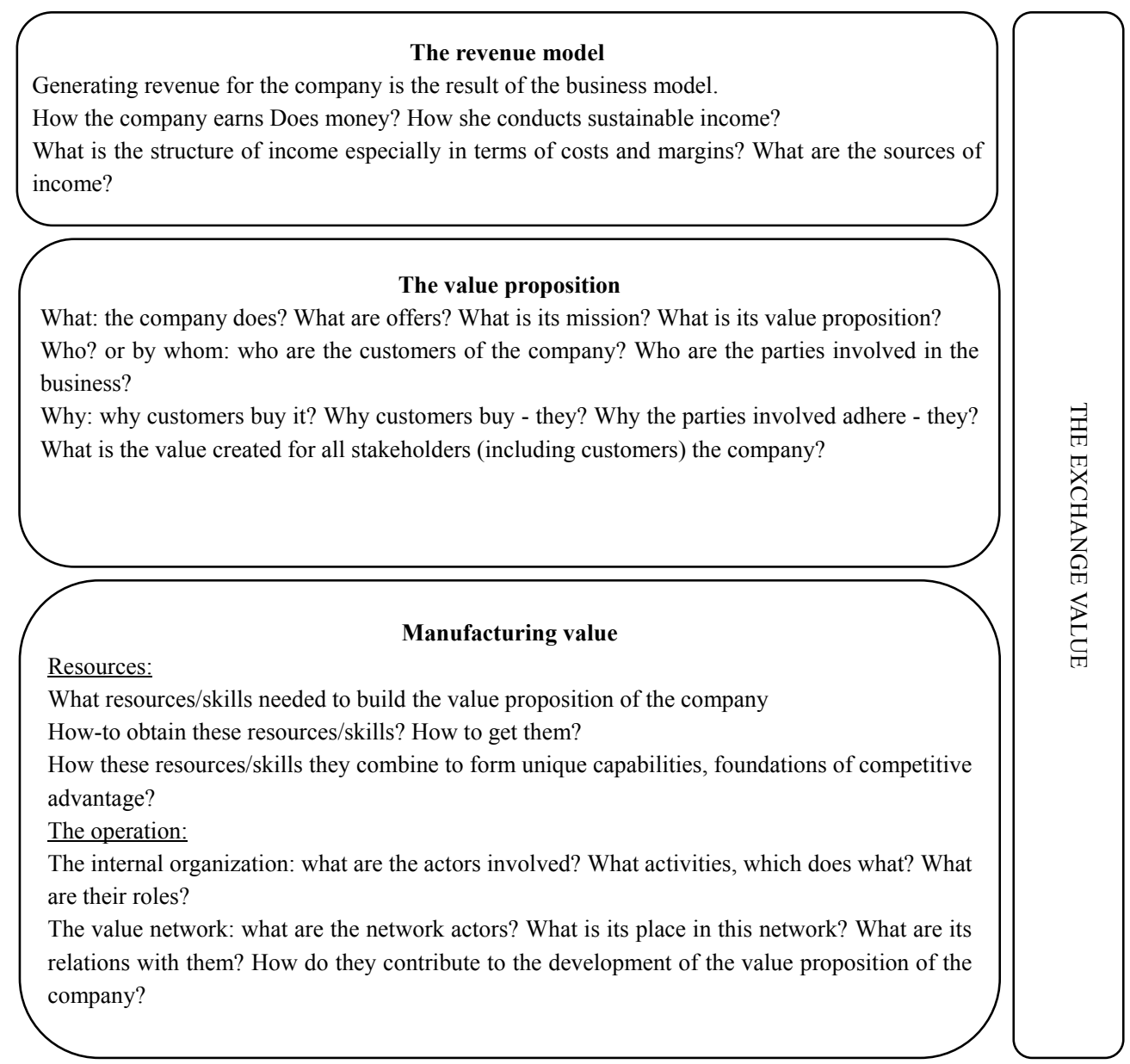

Figure 2. Proposal of synthesis of the Business model concept

Source: Verstraete \& Jouison-Laffitte (2009).

\section{Evolution of Publications on Business Models Thematic}

The literature on Business models makes part of management science and information science disciplines. In this section, we intend to scrutinize the literature to show how it progresses (quantitatively and qualitatively) and to assess its future potential.

The methodology of this study rests on a dual approach:

- A quantitative method, which is meant to list all articles published on this topic in academic journals through a reading panel, and to examine their temporal evolution,

- A qualitative method: it focuses on the analysis of articles that contribute to structure the concept of business model and articles published in the best journals according to Harzing's (Note 2) synthesized rankings.

For publications in English, we are especially interested in the phrase "business model" and its two usual translations in French: "modèle économique" and "modèle d'affaires". Our study uses articles from the EBSCO database and it includes two modules: 'Business Source Premier' i.e. academic journals in English and 'Sales and Management' i.e. academic journals in French.

\subsection{Quantitative Approach}

Quantitative analysis of the literature shows that the term "Business model" appeared for the first time in the literature in the abstract of an article written by Lang, published in Journal of Marketing in 1947, which dealt with insurance. But, it was up to 1960 that the word "business model" was used in the title and abstract of an article written by Jones and published in the Accounting Review.

In fact, the literature on BM underwent a real breakthrough from the mid-1990s onwards, which coincided with a marked increase in establishing Internet start-ups. These two simultaneous movements entailed an increasing use in the literature of terms such as "new business model", "Internet business model", or "e-business model". 
In 2004, there was a peak of publication with 114 articles, listed in the EBSCO database, where BM appears in the abstract. This particularly prolific period was due to the bursting of the bubble in technology stocks in 2000, which revived the debate on the merits of BM of some start-ups. In this respect, we must also take into account that the elaboration and publication of an article normally requires 3 years.

Subsequently, a substantial decline in the number of publications on this topic was noticeable and it stabilized and regained its 2004 standard. Thus, 120 articles on the issue of Business models were being published every year in academic journals. This figure is quite significant compared to the 900 articles published annually by the 25 specialized journals in ranking entrepreneurship of the Association of Business Schools (UK). This proves that this is a dynamic thematic compared to other publications in the field of entrepreneurship in spite of some signs of maturity.

What is interesting is to appreciate this volume in terms of the quality of journals.

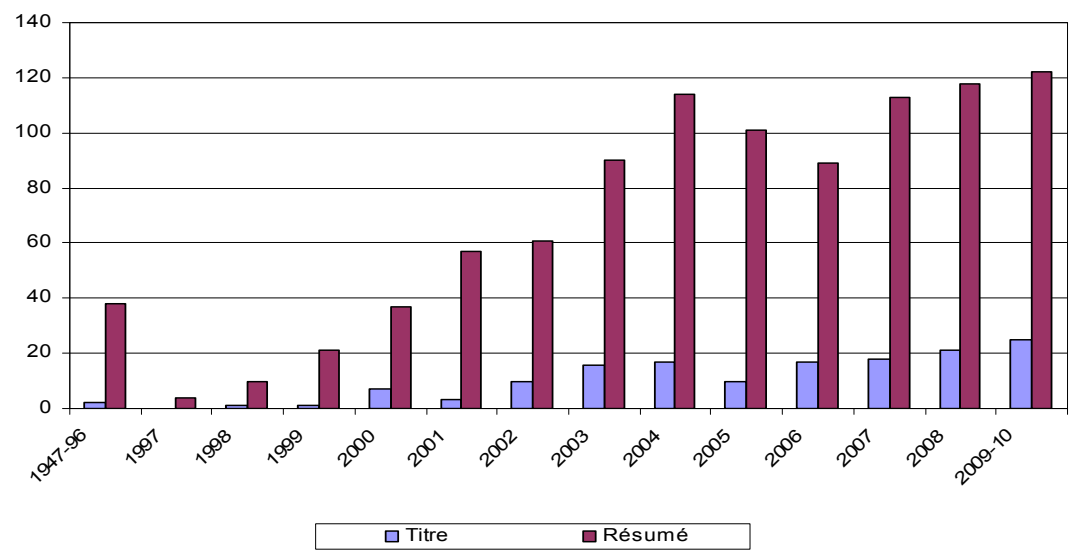

Figure 3. Evolution of publications on business model

(databases: BSP and Sales and Management)

NB: EBSCO inquiry has been conducted in mid-January 2010. We merged the results obtained in 2009 and 2010 because during data collection, some publications of late 2009 were not yet integrated in EBSCO and some early 2010 publications were anticipated and included.

\subsection{Qualitative Approach}

Our analysis is performed in two stages. First, we focus on the analysis of articles that have defined the concept of Business model. Then, we try to identify the articles on BM that were published in leading journals and they are based on rankings of journals in economics and management at the CNRS, the AERES and the Financial Times).

In order to determine the scientific productions that led to the emergence of the concept of Business model, we referred to the quotations in the articles that tried to define it. Then, we completed this approach relying on the relevance index of articles on Business models obtained in EBSCO.

We estimated 20 scientific productions (articles, books, reports or Working Paper, W.P.) displayed in Table 3, but only three articles were published in two prominent academic journals. These journals are Strategic Management Journal (1 C. CNRS) and Harvard Business Review, ranked by Financial Times. Both journals are specialized in strategy and management. The analysis of the overall production also shows that seminal articles are anchored in the field of information science. They are similar to articles published in journals as well as those published in other works i.e. books and reports.

This shows that the publications on this topic have initially struggled to position themselves. Indeed, as this concept was rather ambiguous, the most prominent journals were not interested, except the Harvard Business Review. Moreover, we notice that this phenomenon is not specific to the literature on BM because there are relatively few theoretical articles published in leading journals in general management. 
Table 3. Evolution of the literature on Business model concept

\begin{tabular}{|c|c|c|c|c|c|c|c|c|c|c|}
\hline Authors & $\begin{array}{l}\vec{\Xi} \\
\stackrel{\nu}{0}\end{array}$ & 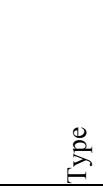 & 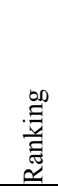 & $\begin{array}{l}\text { : } \\
\text { 泀 } \\
\text { صี } \\
\end{array}$ & 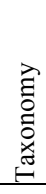 & 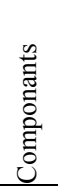 & 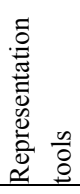 & 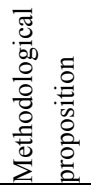 & 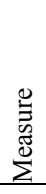 & 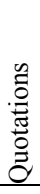 \\
\hline Viscio \& Pasternack & 1996 & Report & NS & $\mathrm{X}$ & $\mathrm{X}$ & & & & & 1 \\
\hline Timmers & 1998 & Article & $\mathrm{NC}$ & $\mathrm{X}$ & $\mathrm{X}$ & & & & & 3 \\
\hline Hamel & 2000 & Book & NS & & & $\mathrm{X}$ & & & $\mathrm{X}$ & 1 \\
\hline Linder \& Cantrell & 2000 & Report & NS & $\mathrm{X}$ & $\mathrm{X}$ & $\mathrm{X}$ & & $\mathrm{X}$ & & 2 \\
\hline Mahadevan & 2000 & Article & $\mathrm{NC}$ & & & $\mathrm{X}$ & & & & 3 \\
\hline Tapscott et al. & 2000 & Book & NS & $\mathrm{X}$ & $\mathrm{X}$ & & $\mathrm{X}$ & $\mathrm{X}$ & & 1 \\
\hline Alt \& Zimmeman & 2001 & Article & $\mathrm{NC}$ & & $\mathrm{X}$ & $\mathrm{X}$ & & & & 3 \\
\hline Amit \& Zott & 2001 & Article & 1 & $\mathrm{X}$ & $\mathrm{X}$ & & & & & 4 \\
\hline Applegate & 2001 & $\mathrm{Wp}$ & NS & $\mathrm{X}$ & $\mathrm{X}$ & & & & & 3 \\
\hline Gordijn \& Akkermans & 2001 & Article & $\mathrm{NC}$ & & & & $\mathrm{X}$ & $\mathrm{X}$ & $\mathrm{X}$ & 1 \\
\hline Hawkins & 2001 & Report & NS & $\mathrm{X}$ & & & & & & 1 \\
\hline Weill \& Vitale & 2001 & Article & $\mathrm{NC}$ & $\mathrm{X}$ & $\mathrm{X}$ & $\mathrm{X}$ & $\mathrm{X}$ & & & 1 \\
\hline Novak \& Hoffman & 2001 & $\mathrm{Wp}$ & NS & $\mathrm{X}$ & $\mathrm{X}$ & & & $\mathrm{X}$ & & 3 \\
\hline Chesbrough \& Rosenbloom & 2002 & Article & $\mathrm{NC}$ & $\mathrm{X}$ & & $\mathrm{X}$ & & & & 3 \\
\hline Magretta & 2002 & Article & FT & $\mathrm{X}$ & & $\mathrm{X}$ & & & & 3 \\
\hline Rappa & 2002 & Report & NS & $\mathrm{X}$ & $\mathrm{X}$ & & & & & 4 \\
\hline Dubosson-Torbay et al. & 2002 & Article & $\mathrm{NC}$ & $\mathrm{X}$ & $\mathrm{X}$ & & & $\mathrm{X}$ & & 1 \\
\hline Afuah \& Tucci & 2001 & Book & NS & $\mathrm{X}$ & & $\mathrm{X}$ & & & $\mathrm{X}$ & 3 \\
\hline Morris et al. & 2005 & Article & 3 & $\mathrm{X}$ & $\mathrm{X}$ & $\mathrm{X}$ & & & & 3 \\
\hline Johnson et al. & 2008 & Article & $\mathrm{FT}$ & & $\mathrm{X}$ & & & $\mathrm{X}$ & $\mathrm{X}$ & 3 \\
\hline
\end{tabular}

NB. Table 3 synthesizes articles that have most structured the Business model concept. It stems from Pateli's approach (2002). The first three columns indicate the name, the type of academic production; book, report, or article as well as its CNRS ranking, especially when it is a journal (NS and NC for non significant and non ranked respectively).

The remaining seven columns explain the type of contribution. Column 5 "Definition" indicates whether or not the author is proposing a pertinent and relatively short definition of the concept. Column 6 "Taxonomy" shows whether or not the author provided a BM. Ranking. Column 7 "Componants" specifies if the author makes any efforts to conceptualize elements composing a Business model. Column 8 "Representation tools" reveals whether or not the author offers a group of tools or a graphic illustration so as to better fathom the various dimensions of a BM. Column 9 "Methodological Proposition" shows if the author suggests any methodology or a modelling attempt. Column 10 "Measure" displays whether or not the author has tried to define indicators to measure BM performance. Column 11 "Quotations" reveals a score from 1 to 4 depending on how many times the article has been quoted in other publications.

After the analysis of the core articles in the literature on business models, we extracted some from EBSCO depending on the CNRS, AERES and Financial Times ranking. Analyzing articles published in leading journals in economics and management, let us identify 55 publications ranking $\mathrm{A}$ or B.

Regarding the disciplinary scope of these publications, there is a huge diversity, which ascertains that the concept of Business model is transversal, but also hierarchical (Figure 4):

- The disciplinary scope, Management and Strategy prevails with $29 \%$ of publications.

- Information Systems (IS), Marketing, Accounting and Finance follow and each one represents over 13\% of the overall publications.

- The decision and innovation theory are the last group; each with more than $9 \%$ of the publications. For decision theory, publications in Management Science are prevalent, which is a reference in management science.

It is salient to note that these articles deal with the issue of business models without necessarily being central. Publication possibilities on this issue seem limited, particularly when the central objective of research is to identify, classify, model, and apply the concept of Business model.

This literature review brings four points:

- The definition of the term business model is based on the concept of "value proposition" which characterizes innovation "product". 
- The literature on business models is replete with works. Therefore, it is not at all voids a concept. This literature is now stabilizing and this tends to show a certain degree of maturity of this topic.

- The topic of business model is targeting all disciplines of management science. Being cross-sectional, it also asserts itself through the diversity of journals in which articles on this subject were published.

- Publications in leading journals in economics and management are related peripheral elements of the concept of Business model.

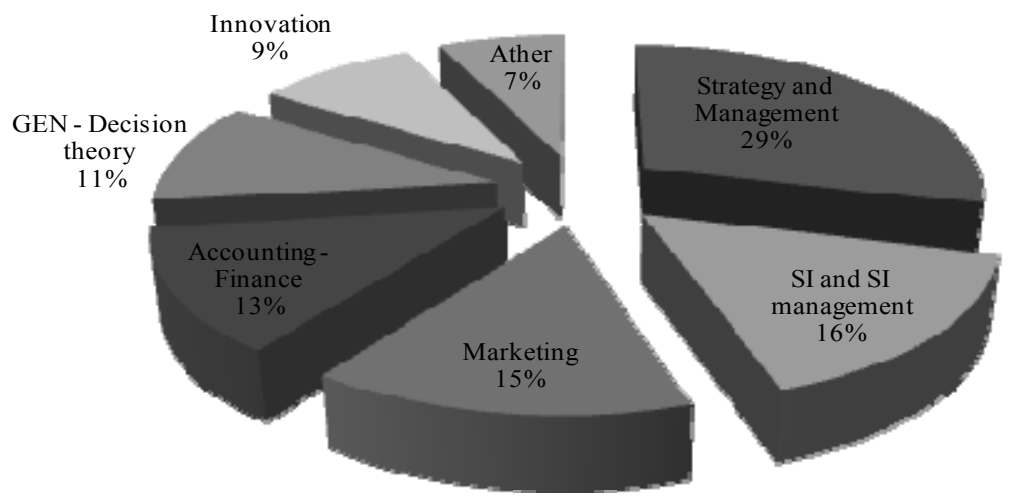

Figure 4. Scope disciplinary articles on business models published in leading journals in economics and management

\section{Business Models and Firms' Performance}

The Business model (BM) has a cross-sectional and multi-faceted representation of the company's working and activity. What renders this concept reliable is its ability to provide an overview to the manager. However, the study of business model as an independent variable is uncommon (Malone et al., 2006). This is due both to the difficulty of operationalizing the models and explaining divergences in firms' interaction with the environment. Despite the scarcity of studies on the business model as a predictor of business performance, there is a growing interest in this concept as a result of recent debates on the determinants of firms Performance or "business specifics" (Rumelt, 1991; Bradenburger \& Stuart, 1996; Nadler et al., 1997).

The objective is not as much to define what a business model in general is as to focus on what makes the specificity of a particular business model, in order to make use of this concept in explaining firms' performance.

\subsection{Firms' Performance}

Performance is considered as a perceptible result of the company's strategy. Many researchers have emphasized the existence of several factors in explaining and estimating the firms' performance (Burns \& Stalker, 1961; Galbraith, 1977; Nadler \& Tushman, 1997; Tosi \& Slocum, 1984). These factors are related to both internal and external factors pertaining to the company (Kotey \& Meredith, 1997; Pearce \& Robinson, 2002). Numerous studies have shown a positive relationship between performance and certain variables such as entrepreneurial choices (Wiklund, 2005; Yusuf, 2002), strategic planning (Fossen et al., 2006) and innovation (Prajogo, 2006; Nilakanta \& Subramanian, 1996). While other studies have focused on the business model to show its role in firms' performance (Malone et al., 2006; Zott \& Amit, 2007).

However, the findings of these studies strongly rely on the notion of performance used because its perception differs according to the company's stakeholder.

For this reason, many researchers have proposed multidimensional approaches to firms' performance (Lumpkin \& Dess, 1996; Venkatraman \& Ramanujam, 1986; Walker \& Ruekert, 1987; Wiklund \& Shepherd, 2005). Particularly, Murphy et al. (1996) suggest that many measures including financial and non-financial objectives should be implemented to better estimate companies' performance. In particular, DeYoung (2005) has developed the profit efficiency model which became very common for comparing traditional activities BM to Internet activities. This method can differentiate the technology-based scale effects and the technology-based experience effects. 
In the following part, we will illustrate some studies on BM in order to better understand the success of some firms. Our goal is to show the existence of a positive relationship between BM and business performance.

\subsection{The Impact of Business Model on Firms' Performance}

Whether from formalized models or not, the first major study on business model as an operation of an asset which determines the performance of the company was conducted by Malone et al. (2006). Their empirical study is based on a business model typology that combines two criteria: the type of asset and the type of ownership held by the firm on that asset when operating it. However, their study lacks a theoretical framework on real resource operation. Indeed, their study considers that each type of asset can be used differently and that this leads to variations in performance, particularly financial performance, in terms of return on assets (ROA).

In a similar way, based on a sample of 202 firms, interviewed between July and November 2009, Aziz and Mahmood (2011) have attempted to explain the performance of manufacturing SMEs in Malaysia through their BM. The main objective of this study was to assess the relationship between the size of the BM (the part of stakeholders, skills, value creation and capture of value) and changes in SMEs performance. These authors suggest that "skill" is the only dimension of the business model that determines SMEs performance and success.

Weill et al. (2006) also considered the assessment of this link out of a typology of BM on a sample of large quoted American companies. This study of the period 1998-2002 is considered as the most important study because the sample of the selected American firms represents $76 \%$ of U.S. Gross Domestic Product. The authors have examined a possible relationship between the types of business model and the firms' performance. For this purpose, They have defined "four basic business models based on what asset rights are sold (Creators, Distributors, Landlords and Brokers) and four variations of each Stock based on what type of assets are Involved (Financial, Physical, Intangible, and Human)". They approximate the performance by the following indicators: Operating Income Before Depreciation (OIBD), Market Capitalization (MC) and Operating Income (OI).

Based on multiple regression, they find that the business model can explain firms' performance more effectively than classification by industry (based on a two-digit code). Moreover, they conclude that market sectors classification can lead to a group of several business models in the same segment. They estimate that the segmentation of firms in the sample, according to the type of business model is more accurate because it captures the main activity of the company. In addition, they show that some business models such as "Broker" or "Landlord" are associated with better firms' performance compared to other business model. This is based on estimation through the OIBD indicator.

Weill et al. (2006) also suggest that the BM, based on intangible assets such as financial, human and intangible assets generate higher performance than those based on physical/material assets. These results were obtained through the use of the "MC" and "OI" as a measure of performance. Ultimately, these authors explain the differences in performance between business models as a result of the conceptual differences between the "seller of asset" and "seller of use". In fact, "seller of use" like investors in training and knowledge are more likely to realize significant benefits related to the specific characteristics of their assets. Notwithstanding, the income of "seller of ownership" are more dependent on the availability of capital and skills of production and distribution. However, the authors believe that much of the observed differences in performance are due to market conditions in the years preceding the bubble/crash of 2000 , resulting in a bubble in technology stocks that led to a better promotion of intangible assets.

To illustrate the ability of a company to explain a firm's performance, Roux (2011) examines the importance of the specificity of a business model over another model from the business model called " RCOV ", which stands for Resources/Skills, Organization, Value proposition and was developed by Warnier et al. (2006), in the industrial sector. The author applies this model to a case of a heavy industry firm, namely Air Liquide. This company positions itself as a global leader in industrial gases and has a business model which has been recording strong growth for over 30 years. In addition, Air Liquide displays stock market performances which were over the French market index, CAC 40, over the past ten years.

The author observes that within the context of heavy industries, mastering the "resources and skills" component is paramount for the success of the company. The importance of this aspect of the business model stems from the nature of these industry products which have particularly low levels of differentiation and a centralized mode of distribution (raw material market obtained through mining).

We suggest another illustration of the relationship between business model and firms' performance in the context of the comparison between the BM and the e-business model provided in the article written by DeYoung (2001) on banking. 
Starting from the idea that "experience" may be a determinant of cost reduction and production efficiency, DeYoung (2001) presented an initial comparison of ROA between newly chartered banks (traditional banks newly created) and Internet-primary banks between 1997 and 1999. He notes that Internet-primary banks have a significantly lower ROA than that of newly chartered bank because of the difficult task of generating deposits and higher non- interest expenses. The very strong gap at the beginning, especially during the first three years, diminishes rapidly thanks to the benefits of technological experience. However, the growth rate of Internet-primary banks declines and joins that of the "newly chartered banks". Only the growth rate of deposit-to-asset ratio for the Internet-primary banks remains behind. The maturity effects are similar for both types of banks. Finally, Internet-primary banks, as well as newly chartered banks cannot achieve the same profitability (ROA) as traditional banks before 10 years at least of activity (DeYoung, 2001).

In another study, DeYoung (2005) confirmed these results using the profit efficiency model. He shows that Internet-primary bank startups tend to underperform the bank branching startups in the USA over the period 1997-2001. This tends to undermine the viability of e-BM Internet banking. We conclude that the success of Internet banking is only possible when a sufficient level of economies of scale and efficient management practices including managing costs are attained.

Most recent results achieved by Cyree et al. (2008), who have examined the performance of banks and newly chartered Internet traditional banks from 1996 to 2003, have provided more details on the performance gap, which partially contradicts DeYoung's studies $(2001,2005)$. Their univariate analysis shows that Internet banks have lower ROA, ROE, loan losses, and net-interest margin, in comparison to newly chartered traditional banks. But they confirm that Internet banks are more profit-efficient than the newly chartered traditional banks.

\section{Conclusion}

We have shown in this paper that the concept of business model has been shaped by successive additions and sedimentation through many contributions that helped to clarify its meaning over time. It is not a "hollow" concept, given the significant works in the literature. However, it tends to stabilize, which evidences that it has reached a certain maturity. It also seems important to reaffirm the multidisciplinary and cross-sectional aspect of this concept. The BM is not a new phenomenon, but it is a re-articulation of some earlier concepts, especially in the business strategy.

Previous studies rather sought to define this concept, but recent studies are more interested in understanding what makes the specificity of BM, in order explain the firms' performance. In addition, various illustrations in this section show that the nature of this relationship varies across sectors and in particular, the evolution of a BM into an e-BM does not guarantee higher performance as has been demonstrated by DeYoung $(2001,2005)$ on Internet banks.

\section{References}

Afuah, A., \& Tucci, C. (2001). Internet Business models and Strategies. Boston: McGraw Hill.

Alt, R., \& Zimmermann, H. (2001). Introduction to Special Section - Business models. Electronic Markets, 11(1), 3-9.

Amit, R., \& Zott, C. (2001). Value Creation in e-Business. Strategic Management Journal, 22, 493-520. http://dx.doi.org/10.1002/smj.187

Applegate, L. M. (2001). Emerging e-Business models: Lessons from the Field. Harvard Business School, 26(juillet), 14-23.

Bradenburger, A. M., \& Stuart, H. W. (1996). Value-Based Business Strategy. Journal of Economics and Management Strategy.

Campbell, A. (1998). The Agile Enterprise: Assessing the Technology Management Issues. International Journal of Technology Management, 15(1), 82-95. http://dx.doi.org/10.1504/IJTM.1998.002595

Carrier, C. (2009). L'enseignement de l'entrepreneuriat: au delà des cours magistraux, des études de cas et du plan d'affaires? Revue de l'Entrepreneuriat, 8(2).

Casadesus-Masanell, R., \& Ricart, J. E. (2010). From Strategy to Business models and onto Tactics. Long Range Planning, 43, 195-215. http://dx.doi.org/10.1016/j.lrp.2010.01.004

Catherine, D., Corolleur, F., \& Coronini, R. (2002). Les fondateurs des nouvelles entreprises de biotechnologies et leurs modèles d'entreprise. Une approche par les compétences et les ressources illustrées sur le cas français. Revue Internationale PME, 15(2). 
Chesbrough, H., \& Rosenbloom, R. S. (2002). The role of the business model in capturing value from innovation: evidence from Xerox Corporation's technology spin-off companies. Industrial and Corporate Change, 11(3), 529-555. http://dx.doi.org/10.1093/icc/11.3.529

Cyree, K. B., Delcoure, N., \& Dickens, R. (2008). An examination of the performance and prospects for the future of internet-primary banks. Journal of Economics and Finance, June.

Demil, B., \& Lecocq, X. (2010). Business model Evolution: In Search of Dynamic Consistency. Long Range Planning, 43, 227-246. http://dx.doi.org/10.1016/j.lrp.2010.02.004

DeYoung, R. (2001). The financial progress of pure-play internet banks. Bank for International Settlements, Monetary and Economic Department, BIS Papers n 7, 80-86.

DeYoung, R. (2005). The Performance of Internet-Based Business models: Evidence from the Banking Industry. Journal of Business, 78(3), 893-947. http://dx.doi.org/10.1086/429648

Dubosson-Torbay, M., Osterwalder, A., \& Pigneur, Y. (2002). eBusiness model Design, Classification and Measurements. Thunderbird International Business Review, 44(1), 5-23. http://dx.doi.org/10.1002/tie.1036

Fisken, J., \& Rutherford, J. (2002). Business models and investment trends in the biotechnology industry in Europe. Journal of Commercial Biotechnology, 8(3), 191-199.

Forge, S. (1993). Business models for the Computer Industry for the Next Decade: when will the Fastest Eat the Largest? Futures, 923-26. http://dx.doi.org/10.1016/0016-3287(93)90060-7

Fossen, R. J. S. V., Rothstein, H. R., \& Korn, H. J. (2006). Thirty-five years of strategic planning and firm performance research: a meta-analysis. Paper presented at the Academy of Management.

Gagnon, S. (2003). E-business model Innovation and Capability Building. Discussion Paper No. 2003/40, World Institute for Development Economics Research, United Nations University, April.

Galbraith, C., \& Schendel, D. (1983). An Empirical Analysis of Strategy Types. Strategy Management Journal, 4, 153-173. http://dx.doi.org/10.1002/smj.4250040206

George, G., \& Bock, A. J. (2011). The Business model in Practice and its Implications for Entrepreneurship Research. Entrepreneurship Theory and Practice, 35(1), 83-111. http://dx.doi.org/10.1111/j.1540-6520.2010.00424.x

Ghosh, S. (1998). Making Business Sense of the Internet. Harvard Business Review, March-April, 127-35.

Gordijn, J., \& Akkermans, H. (2001). Designing and Evaluating e-Business models. IEEE Intelligent Systems, July-August, 11-18. http://dx.doi.org/10.1109/5254.941353

Gordijn, J., \& Akkermans, H. (2007). Business models for Distributed Energy Resources In a Liberalized Market Environment. The Electric Power Systems Research Journal, 77(9), 1178-1188. http://dx.doi.org/10.1016/j.epsr.2006.08.008

Hamel, G. (2000). Leading the revolution. Boston: Harvard Business School Press.

Han, D., \& Han, J. (2001). Value-based Strategy for Internet Business. MIT Ecommerce Research Forum.

Hawkins, R. (2001). The "Business model" as a Research Problem in Electronic Commerce. SPRU - Science and Technology Policy Research.

Jones, G. M. (1960). Educators, Electrons, and Business models: A Problem in Synthesis. Accounting Review, $35(4), 19-626$.

Ketchen, D. J., James, B. T., \& Snow, C. C. (1993). Configurational Approaches to Organization Organizational Configurations and Performance: A Comparison of Theoretical Approaches (Special Research Forum). Academy of Management Journal.

Kotey, B., \& Meredith, G. G. (1997). Relationship among owner/manager personal values business strategies, and enterprise performance. Journal of Small Business Management, 37(2), 37-62.

Kukalis, S., \& Senf, G. A. (1994). Object Oriented Concepts Applied to Strategic Planning. International Journal of Management, 11(2).

Kuratko, D. F. (2005). Entrepreneurship Education: Development, Trends, and Challenges. Entrepreneurship Theory and Practice, 29(5). http://dx.doi.org/10.1111/j.1540-6520.2005.00099.x

Linder, J., \& Cantrell, S. (2000). Changing Business models: Surveying the Landscape. Accenture Institute for Strategic Change. 
Lippman, S. A., \& Rumelt, R. (2003). The Payment Perspective: Micro-Foundations of Resource Analysis. Strategic Management Journal. http://dx.doi.org/10.1002/smj.346

Loilier, T., \& Tellier, A. (2001). La configuration des réseaux d'innovation : une approche par la proximité des acteurs. Revue d'Economie Régionale et Urbaine, 4(octobre), 559-580. http://dx.doi.org/10.3917/reru.014.0559

Lumpkin, G. T., \& Dess, G. G. (1996). Clarifying the entrepreneurial orientation construct and linking it to performance. The Academy of Management Review, 21(1), 135-172.

Magretta, J. (2002). Why Business models Matter. Harvard Business Review, May, 86-92.

Mahadevan, B. (2000). Business models for Internet-based e-Commerce: An anatomy. California Management Review, 42(4), 55-69. http://dx.doi.org/10.2307/41166053

Malone, T. W., Weill, P., D'Urso, V. T., Herman, G., \& Woerner, S. (2006). Do Some Business models Perform Better than Others? MIT Sloan Research Paper No. 4615-06, MIT Sloan.

McQuillan, J. (1996). The Internet Gold Rush. Business Communications Review, 10.

Morris, M., Schindehutte, M., \& Allen, J. (2005). The entrepreneur's business model: Toward a unified perspective. Journal of Business Research, 58(6), 726-735. http://dx.doi.org/10.1016/j.jbusres.2003.11.001

Nadler, D., Nadler, D. A., \& Nadler, B. (1997). Competing by Design: the Power of Organizational Architecture.

Novak, T. P., \& Hoffman, D. L. (2001). Profitability on the Web: Business models and Revenue Streams. eLab Position Paper, Owen Graduate School of Management, Vanderbilt University, janvier, 9-18.

O’Brien, J., Sales, R., Schmerken, I., \& Tomasula, D. (1996). Web Warriors Redefine the Street. Wall Street and Technology, 60.

Osterwalder, A., \& Pigneur, Y. (2003). An Ontology for E-Business models.

Pateli, A. (2002). A Domain Area Report on Business models. Athens Universityof Economics and Business.

Patterson, S., \& Altieri, J. (1993). Business modeling Provides Focus for Upstream Integration. Oil \& Gas Journal, 43.

Pearce, J. A., \& Robinson, R. B. (2002). Strategic management. Boston: Mc- Graw Hill.

Penrose, E. T. (1959). The Theory of the Growth of the Firm. New York.

Porter, M. E. (1985). Competitive advantage: Creating and sustaining superior performance. New York: Free Press.

Porter, M. E. (2001). Strategy and the Internet. Harvard Business Review, June.

Potok, T. E., \& Vouk, M. A. (1997). The Effects of the Business model on Object Oriented Software Development Productivity. IBM Systems Journal, 140-161. http://dx.doi.org/10.1147/sj.361.0140

Prajogo, D. I. (2006). The relationship between innovation and business performance - a comparative study between manufacturing and service firms. Knowledge Process Management, 13(3), 218-225. http://dx.doi.org/10.1002/kpm.259

Rappa, M. (2002). Managing the digital enterprise - Business models on the Web. North Carolina State University.

Reader, D., \& Watkins, D. (2006). The Social and Collaborative Nature of Entrepreneurship Scholarship: A Co-Citation and Perceptual Analysis. Entrepreneurship: Theory and Practice, 30(3). http://dx.doi.org/10.1111/j.1540-6520.2006.00127.x

Rédis, J. (2007). Le Business model : notion polymorphe ou concept gigogne? $5^{\text {ème }}$ Congrès de l'Académie de l'entrepreneuriat, Sherbrooke, Québec.

Roux, B. (2011). De l'Utilité du Business model en tant que Variable Explicative de la Performance des Firmes. AIMS 2011 Conference, Nantes, 7-9 June.

Rumelt, R. P. (1991). How Much Does Industry Matter? Strategic Management Journal, 12(3), 167-185. http://dx.doi.org/10.1002/smj.4250120302

Shane, S., \& Venktaraman, S. (2000). The Promise of Entrepreneurship as a Field of Research. The Academy of Management Review, 25(1). 
Slywotzky, A., \& Morrison, D. (1997). The Profit Zone. Times Business.

Subramanian, A., \& Nilakanta, S. (1996). Organizational innovativeness: exploring the relationship between organizational determinants of innovation, types of innovations, and measures of organizational performance. Omega, 24(6), 631-647. http://dx.doi.org/10.1016/S0305-0483(96)00031-X

Sumaiyah Abd Aziz, S., \& Mahmood, M. (2011). The relationship between business model and performance of manufacturing small and medium enterprises in Malaysia. African Journal of Business Management, 5(22), 8918-8932.

Timmers, P. (1998). Business models for electronic markets. Electronic Markets, 8(2), 2-8. http://dx.doi.org/10.1080/10196789800000016

Tosi, H. L., \& Slocum, J. W. J. (1984). Contingency theory: some suggested Directions. Journal of Management, 10(1), 9-26. http://dx.doi.org/10.1177/014920638401000103

Venkataraman, N., \& Ramanujam, V. (1986). Measurement of business performance in strategy research: a comparison of approaches. The Academy of Management Review, 11(4), 801-814.

Venkatraman, N. (2000). Five Steps to a Dot.com Strategy. Sloan Management Review, 15-28.

Venkatraman, N., \& Henderson, J. C. (1998). Real Strategies for Virtual Organizing. Sloan Management Review, $33-48$.

Verstraete, T., \& Jouison-Laffitte, E. (2009). Business model pour Entreprendre -Le modèle GRP: théorie et pratique. de Boeck Université, mars.

Viscio, A. J., \& Pasternack, A. (1996). Toward a new business model. Retrieved from: http://www.strategy-business.com/press/16635507/14974 (dernier accès novembre 2009).

Walker, O. C. J., \& Ruekert, R. W. (1987). Marketing's role in the implementation of business strategies: a critical review and conceptual framework. Journal of Marketing, 51(3), 15-33. http://dx.doi.org/10.2307/1251645

Warnier, V., Demil, B., \& Lecocq, X. (2010). Le Business model: l'Oublié de la Stratégie? 13ème conférence de l'AIMS. Normandie, Vallée de Seine.

Watkins, K. (2009). Back to the Future in Entrepreneurship Research? Séminaire donné à la Southampton Business School.

Weill, P., \& Vitale, M. (2002). What IT infrastructure capabilities are needed to implement e-business models? MIS QuaterlyExcecutive, 1(March), 17-34.

Wiklund, J., \& Shepherd, D. A. (2005). Entrepreneurial orientation and small business performance: a configurational approach. Journal of Business Venturing, 20(1), 71-91. http://dx.doi.org/10.1016/j.jbusvent.2004.01.001

Yunus, M. (2010). Building Social Business models: Lessons from the Grameen Experience. Long Range Planning, 43, 308-325. http://dx.doi.org/10.1016/j.lrp.2009.12.005

Yusuf, A. (2002). Environmental uncertainty, the entrepreneurial orientation of business ventures and performance. International Journal of Commerce and Management, 12(3\&4), 83-103. http://dx.doi.org/10.1108/eb047454

Zott, C., \& Amit, R. (2010). Business model Design: An Activity System Perspective. Long Range Planning, 43, 216-226. http://dx.doi.org/10.1016/j.lrp.2009.07.004

\section{Notes}

Note 1. An enquiry carried out by Accenture Institute for Strategic Change, 2000.

Note 2. http://www.harzing.com/jql.htm. 